\title{
EJSBS
}

The European Journal of Social \&

Behavioural Science

ISSN: 2301.2218 (ONUINE)
OPEN ACCESS

The European Journal of Social and Behavioural Sciences

EJSBS Volume XXX, Issue I (eISSN: 2301-2218)

\section{REVITALISING ORGANISATIONS’EMERGENCY SUCCESSION PLANNING IN THE FACE OF THE COVID-19 OUTBREAK}

\author{
Yasmeen Bano ${ }^{\mathrm{a}}$, Siti Sarah Omar ${ }^{\mathrm{b}}$, Fadillah Ismail $^{\mathrm{c} *}$ \\ ${ }^{a}$ Universiti Tun Hussein Onn Malaysia,86400Parit Raja,Johor, Malaysia, gp160150@siswa.uthm.edu.my \\ ${ }^{b}$ Universiti Tun Hussein Onn Malaysia,86400Parit Raja, Johor, Malaysia, sarah@uthm.edu.my \\ ${ }^{c}$ Universiti Tun Hussein Onn Malaysia, 86400Parit Raja, Johor, Malaysia, fadillah@uthm.edu.my
}

\begin{abstract}
The purpose of this study is to provide an overview of the need for emergency succession planning during the current covid-19 pandemic. Today, organizations cannot ignore the fact that their employees are their most valuable capital. The pandemic has spread like wildfire with serious consequences on multiple sectors, with most experts postulating that the world is facing the worst recession ever experienced. This pandemic has seriously impacted all businesses, with some permanently shut down like food and beverage, hotels and airlines leaving millions of people jobless on temporary or permanent layoffs. Some, on the other hand, are benefiting from this grim situation such as healthcare products like mask and glove manufacturing, and remote-conferencing services such as Zoom. In this situation, organizations must focus on key changes that can sustain business continuity. This pandemic has forced all organizations to relook and revitalise their emergency succession plan. This study is a review paper which will highlight the difference between long-term and emergency succession planning, the major challenges faced by all organizations and, suggests best options for preparing emergency succession planning during the pandemic crises. This study applies to all sectors of business.
\end{abstract}

Keywords: Covid-19, Emergency succession planning, pandemics, human resources

(C) 2021 Published by European Publisher. www.europeanpublisher.com

${ }^{*}$ Corresponding author.

E-mail address: gp160150@siswa.uthm.edu.my

doi: $10.15405 /$ ejsbs.285

This work is licensed under a Creative Commons Attribution-NonCommercial-NoDerivatives 4.0 International License. 
https://doi.org/10.15405/ejsbs.285

eISSN: 2301-2218 / Corresponding Author: Fadillah Ismail

Selection \& Peer-review under responsibility of the Editors

\section{Introduction}

\subsection{The emergence and brief history of Covid-19}

The Coronavirus disease, or more commonly known as COVID-19, is a highly infectious disease. which has affected almost every country in the world (Yeo et al., 2020). Covid-19 was detected at the end of December 2019 in Wuhan city of the central Hubei province of China. Over the next three months, the infection spread around the world and rapidly increased the number of deaths. This outbreak affected more 114 countries within a few months. The World Health Organization (WHO) had reported a total number of 693,224 confirmed infected cases with 35, 000 deaths in 204 countries around the world on 30th March 2020. As of 14th September 2020, the recorded number of confirmed cases around the world had increased to 307,930 within a span of 24 hours; the highest number recorded since the start of the outbreak (WHO, 2020a).

Sim (2020) in tracing the spread of the virus outside of China found that, the virus had initially spread to other countries within Asia such as Korea, and from there to the Middle East via Iran, reaching Southern Europe through Italy and Spain, after which it affected Northern Europe through the UK. The ongoing Covid-19 outbreak had also devastated South East Asian countries such as Singapore. As of February 25, 2020, Singapore recorded the fourth-highest number of confirmed cases (Liang et al., 2020). China has announced the first death of a 61 year-old man on January 11, 2020 due to complications arising from Covid-19. The second death was recorded outside of China on February 2, 2020 in the Philippines. Considering the global threat, on March 11, 2020, the WHO officially declared the novel coronavirus disease (COVID-19) a pandemic due to increasing numbers of infections up to 118,000 in over 110 countries (Ducharme, 2020).

Ross et al. (2015) have quoted previous research to highlight that in the past, infectious diseases had, with regularity, appeared and globally infected populations almost every decade, but recently, they contended that the frequency between pandemic was alarming as the duration between outbreaks seemed to be disturbingly shorter as evident with Covid-19 (2019), Ebola (2014), MERS (2012), H1N1 (2009), H1N5 (2007) and SARS (2003). In this respect, an important finding of Taubenberger and Morens's (2006) study conducted on the 1918 influenza outbreak "which caused around 50 million deaths worldwide, remains an ominous warning to public health" is timely to note in the case of the current pandemic.

\subsection{The Consequences of Covid-19 on Various Economic Sectors}

The world is now facing the socio-economic consequences of Covid-19 pandemic which has affected many businesses depending on the sector, transforming this into a 
https://doi.org/10.15405/ejsbs.285

eISSN: 2301-2218 / Corresponding Author: Fadillah Ismail

Selection \& Peer-review under responsibility of the Editors

worldwide concern. In the Education sector, all levels of learning institutes from preschool to university level have been affected. Almost every country has imposed a nation-wide closure of learning institutes. Covid-19 has also affected postgraduate researchers with the cancellation of many conferences and the shift of teaching and learning to online platforms.

Although the need for some medical supplies has significantly increased during the Covid-10 outbreak, losing healthcare workers is a challenge for the healthcare system globally. The fear of infection has resulted in many health workers refusing to work, and this is one sector where the work cannot be done remotely. More tragic is the loss of healthcare workers to the Covid-19 infection and even death, causing a dire shortage of workforce in the healthcare industry.

Undeniably, the hardest-hit industry is the tourism and hospitality industry and, by default, aviation, which has seriously affected both travel supply and demand. Nicola et al. (2020) have highlighted this in their study which found that "The world travel and tourism council has warned that 50 million jobs in the global travel and tourism sector may be at risk (p. 188)". The sports industry and real estate industry both face great uncertainty due to the Covid-19 outbreak. The world's largest sporting events such as the Olympics have been postponed till 2021. Similarly, the real-estate housing sector has also been affected due to delaying buying and renting houses during the lockdown. The same can be said for the car manufacturing industry and related industries. These industries are facing the repercussions of more and more people losing their sources of income. In contrast, the food manufacturing industry has benefited due to the increased demand brought on by panic buying which conversely has resulted in the shortage of certain food and household products like toilet paper. Other industries that have benefitted significantly from this pandemic are those related to the manufacture of certain healthcare products like sanitisers, masks and gloves. According to a glove manufacturer, its revenue skyrocketed to RM3.11 billion in 2020 from RM1.19 billion the previous year and based its tremendous growth on a global surge in demand for gloves on the back of the Covid-19 pandemic (New Straits Times Business, 2020)

This pandemic is changing human attitudes to adaptation and survival. Organizations are observing and reacting to different challenges during this Covid-19 crisis which requires the redesigning of business models to cater to a new normal. These new norms are forcing organizations to redefine the work structure beyond the traditional office environment. The importance of human capital has been described by Rothwell (2011) as "Human Capital management regards people as key assets. Humans found companies, discover new markets, invent new products or services, and generally provide the spark that leads to business formation and competitive advantage" (p. 5). In short, an organisation's survival is grounded 
https://doi.org/10.15405/ejsbs.285

eISSN: 2301-2218 / Corresponding Author: Fadillah Ismail

Selection \& Peer-review under responsibility of the Editors

in its human assets, in particular its leadership, failing which, its continuity is susceptible to external forces like the current pandemic.

This pandemic is forcing organizations to respond to the necessity of having succession planning in place for business continuity. If organizations do not already have one in place, it is high time to refresh succession planning to meet unseen emergencies such as this pandemic or the absence of a key employee. Organizations need to prepare for any international crises like the current global pandemic by retaining their employees. Employees, especially those in key positions, may depart from an organization unpredictably. In such cases, only an emergency succession plan can help to fill vacant positions with immediate effect and with minimum loss to the organisation. Hence, it is vital to identify a number of people who can take up the immediate responsibility in the interim until a long-term successor is identified.

\section{Purpose of the Study}

The purpose of this study is to provide an overview of the challenges faced by all organizations due to the impact of the Covid-19 pandemic on business continuity and the importance of having succession planning in place to ensure business continuity and to provide peace of mind to the employees.

\section{Research Questions}

The research questions driving this study are;

3.1 What are the differences between differences between Emergency Succession Planning and Long-term Succession Planning?

3.2 What are the challenges facing by organizations' emergency succession planning during the Covid-19 pandemic?

3.3 What are the steps to prepare for emergency succession planning?

\section{Research Method}

This paper is based on a fairly extensive literature review and the literature search for this paper relied on five scientific databases, namely: EBSCOhost, Emerald, ProQuest, Sage and, ScienceDirect. In this study, specific search terms were used when accessing databases. The searches were carried out using academic journals (science direct, emerald,), relevant websites such as the World Health Organization and government organizations such as the 
https://doi.org/10.15405/ejsbs.285

eISSN: 2301-2218 / Corresponding Author: Fadillah Ismail

Selection \& Peer-review under responsibility of the Editors

Centre for Disease Control and Prevention. Some other relevant online articles were also cited in the literature.

The exclusion criteria were non-academic researchers and other languages. The search criteria for databases included 'pandemics', 'emergency planning', 'Covid-19', 'succession planning' related terminology. Categories searched were abstract, titles, and keywords. Preference was given to publications dated between 2019 -2020. The primary search yielded a total of 200 articles, which were further screened by analyzing the title and abstract of each paper, using exclusion criteria. Applying these criteria, a total of 100 papers remained, which were subsequently subject to in-depth reading. The final filtering yielded a total of 24 articles which met the criteria and were included in the final database.

\section{Findings from the Literature Review}

\subsection{Differences between Emergency Succession Planning and Long-term Succession Planning}

There is a significant difference between emergency succession planning and long-term succession planning. Rothwell (2011) introduced replacement planning as emergency succession planning which refers to the process of distinguishing short-term alternatives of employees who can take over critical positions during unexpected events and emergencies such as Covid-19 outbreak. An emergency succession plan is defined by Rothwell (2011, p. 91) as a well-developed emergency succession plan is one that takes an evergreen approach to succession planning, so that succession planning is a regular board or management team agenda item, which in turns puts a company and its board in a better position to withstand crises and to move swiftly to maintain short term stability and business continuity.

Organizations should not confuse emergency succession planning with longer-term succession planning, because longer-term succession planning focuses on developing a pool of employees through promotions in order to retain the best talent within the organization.

Seen from this perspective, emergency succession planning focuses on meeting the demands of emergencies. With emergency succession planning in place, organizations can avoid long delays in making important decisions. However, Rothwell (2011) has given replacement planning as a means of risk for the unplanned loss of key personnel. According to Rothwell (2011) and Wolfe (1996), succession planning entails a longer-term and extensive approach towards the training and replacement of key individuals. Cavanaugh (2017) recommended that "emergency successions should be strategically planned prior to the 
https://doi.org/10.15405/ejsbs.285

eISSN: 2301-2218 / Corresponding Author: Fadillah Ismail

Selection \& Peer-review under responsibility of the Editors

occurrence of an actual institutional emergency to provide stability and order" (as cited in Swanson, 2018, p. 74).

In fact, many organizations are not successful in identifying and developing potential internal talent for leadership positions during emergencies which can happen as a result of tragic circumstances. One example of this occurred when 172 corporate vice presidents died during the destruction of the World Trade Centre in 2001 (Rothwell, 2011). Similarly, the Covid-19 outbreak also presents the real possibility that many employees could fall ill at the same time creating a risk to leadership continuity in small to medium sized organizations as well as in multinationals. Success planning in large organizations is a complicated matter requiring the convening of boards to conduct succession planning, all of which will involve more time that the organization is exposed to risk. Without an effective succession plan in place, organizations became dependent on external hiring which cost time and money.

\subsection{Challenges facing by Organizations' Emergency Succession Planning during the Covid- 19 pandemic}

The Covid-19 pandemic has been an incredibly difficult experience in so many ways. In this section, the paper will explore the effects of the pandemic on several aspects of organizational operations. The economic effects of the Covid-19 pandemic are due to the temporary closing of many sectors and businesses, which has caused a reduction in the workforce with 3.3 billion global workforce losing their livelihood. Sim (2020) found that "the economic impacts are affecting the most vulnerable workers in society; those less skilled, low paid, those in the informal sectors" (p. 281). The existing studies highlight some challenges faced by organizations around the world such as lack of a succession planning, slacking of employees' productivity and increase in anxiety.

\subsubsection{CEO and Critical Roles Succession}

The biggest challenge for many organizations is that, according to Santora (2020); Many CEOs do not plan for succession. Indeed, they often share the false belief that they are immortal; but, like the rest of us, they will die. CEOs Jean Philippe Ruggieri (Nexity Group), Mike Dean (Mahdlo), and Don Welge (Gilster-Mary-Lee) have all died from COVID-19-related complications. Without an emergency CEO succession plan, these CEOs could have seriously jeopardized the sustainability of their companies. Today, many CEOs and their boards simply give "lip service" to CEO succession. Larcker and Miles (2010) found that more than 50\% of companies in their survey were unable to "immediately name a successor. (as cited in Santora, para 3) 
They also found that these companies were unprepared for a CEO succession process" He goes on to cite a study conducted by Hooijberg and Lane (2016) which stated three reasons for not putting in place a CEO succession plan. Firstly, there is a mismatch between the company strategy and CEO perspective. The second reason involves CEO insecurities and the third is the failure to identify mid-level managers for executive development training. During emergency succession, a list of potential interim candidates for all leadership positions not just CEO is essential if key employees are indisposed or unavailable for any reason. (Santora, 2020, para 4)

\subsubsection{Destructive Absenteeism of Employees}

The Covid-19 outbreak has created a number of challenges for many organizations such as employees' unexpected absenteeism. This outbreak has had an unprecedented effect on working life leading to high rates of absenteeism among employees. During this type of outbreak, employee absenteeism can be categorized into different reasons for not coming in to work. Some employees do not go for work due to fear of getting infected. Others may be absent from work as they have to take care of their sick family members. Other causes of absenteeism amongst employees are due to self-isolation, sickness, and sudden deaths. Koonin (2020) found that "absenteeism is one of the major threats to a business during a severe pandemic. The estimated absenteeism during a severe pandemic is $20-40$ percent" (p. 6). Working remotely can also weaken one's organizational or communal identification with coworkers (Bartel et al., 2012) which could be a causal factor in the slacking off in employee motivation to report for work.

\subsubsection{Employee Productivity}

Employee absenteeism naturally would have organizations concerned about the effect of Covid-19 on employee productivity. For many employees, the Covid-19 crisis has disrupted the way they work and even where they work. Millions of employees are now grappling with a remote work environment. The world's workforce is now facing an unprecedented work from home experience. Prolonged isolation has been found to impact on productivity. Workers in alternative work arrangements may feel more disconnected from their colleagues (Turkle, 2011). For instance, it is not easy for parents to maintain the same levels of efficiency when working from home with disruptions caused by children and/or the elderly being in the same working space. Lockdowns caused by this pandemic have necessitated a shift in skillsets, attitudes, and expectations of productivity levels. New challenges have emerged in organizations with employees working remotely such as unmanageable workloads, slow 
https://doi.org/10.15405/ejsbs.285

eISSN: 2301-2218 / Corresponding Author: Fadillah Ismail

Selection \& Peer-review under responsibility of the Editors

internet connections, work life balance, and poor communication. In such circumstances, employee productivity is bound to be affected.

\subsubsection{Employee Anxiety}

It is not surprising that Covid-19 has affected all levels of organisations, in particular employees causing not just anxiety but also panic, stress, and depression putting them at significant risk of adverse mental health outcomes. The major factors causing anxiety among health workers are long working hours, physical fatigue, and separation from families (Lee et al., 2020). According to the WHO Director-General, "Social isolation, fear of contagion, and loss of family members is compounded by the distress caused by loss of income and often employment" (WHO, 2020b, para 2). Similarly, the new norms put in place to flatten the curve by many countries' governments such as travel restrictions, social distancing and quarantine are also affecting people's mental health. Lack of employment can lead to mental health decline. In addition, managers and supervisors are also subject to similar stress because their responsibilities to their staff create pressure on them. It is undeniable that many employees are suffering in silence, which will undoubtedly affect their overall productivity.

\subsubsection{Relocation of Right Skilled Talent}

It is clear that the Covid-19 outbreak has triggered unprecedented changes to the world of work. The biggest challenge for organizations is to relocate the right skilled talent at the right place (example, location). It is a fact that remote working culture will not go away very soon. Travel restrictions and self-isolation have led to reducing the workforce across all sectors resulting in many people losing their jobs. Relocation means working in a new environment under new conditions. For a successful transfer of productivity, employees would require a certain period of time to adjust to this transition.

\subsection{Preparing for Emergency Succession Planning}

From improving communication to providing mental health first aid training, there are several ways to improve working environment of workforce during the covid-19 crisis.

\subsubsection{Importance of Business Continuity}

The Covid-19 outbreak has spotlighted the priority of ensuring business continuity in the face of an unexpected event. This pandemic has challenged organizations to negotiate business operations for long term sustainability. Organizations are currently facing serious uncertainty causing instability in business continuity. In this rapidly changing environment, 
https://doi.org/10.15405/ejsbs.285

eISSN: 2301-2218 / Corresponding Author: Fadillah Ismail

Selection \& Peer-review under responsibility of the Editors

organizations need to rely on their most important asset that is their workforce. This disease has sunk many organisations without a master survival plan to ensure business continuity. If organizations do not have a business continuity plan yet, the upper management has no choice but to reassess their operations to meet the new challenges or sink. Some organizations may have to consider promoting their employees through a succession plan to tackle the current challenging environment. The concept of working from home is one of the practices of telecommunication which can ensure business continuity operations.

A traditional business continuity management program can be the core of a plan that addresses the challenges brought on by the Covid-19 crises. A regular plan of reviews can also be included in the business continuity plan. To ensure business continuity, organizations can establish a crisis team which can act in a timely manner to coordinate relevant response efforts. This crisis team would ensure consistency across all departments and activities.

\subsubsection{Implementation of Existing Formal and Informal Succession Plan}

Organizations can use a variety of formal and informal succession plans to identify those employees with the potential to take the next step in their career. This can be done by assessing competencies in performance reviews. It is important to communicate during the process of identifying a potential successor to ensure employees understand the succession process. In this, the Human resources unit have an important role to facilitate the succession process by managing assessment process and maintaining relevant track records of the talent pool. The succession planning process is neither a product oriented nor a one-time event. As its name "planning" implies, it is an ongoing method to develop leadership talent.

\subsubsection{Effective Communication Plan}

An emergency communication plan can be deployed to employees directly impacted by the change. These plans should include broad external and internal communication such as press releases, emails, meetings and so on. Small group communication between supervisors and subordinates must be included in the effective plan. The flow of communication is vital during emergencies to maintain the confidence of both employees and employers. Providing timely and accurate information by tele networking to all employees can be very beneficial to business continuity.

Communicating with the entire workforce whether they are at the worksite or other locations, will be a critical capability. A successful emergency communication plan should also identify mechanisms to ensure communication with all employees. Employers can establish and regularly update telephone, text and email rosters for staff, so that they can 
https://doi.org/10.15405/ejsbs.285

eISSN: 2301-2218 / Corresponding Author: Fadillah Ismail

Selection \& Peer-review under responsibility of the Editors

rapidly communicate protective measures (such as advice about staying away from the workplace if they are ill and information about alterations in leave policies), whether the workplace is open for business, and other critical information during unforeseen circumstances such as this pandemic.

\subsubsection{Selection of Interim Replacements}

In a crisis, the criteria to find an interim successor depends on the characteristics of a leader who can understand the emergency and maintain business continuity for the shorter term. It is also important to consider specific skills such as communication skills. A selected interim successor must have the necessary competencies to ensure that the organization is in good hands until a permanent successor is selected. Most often, interim successors come from within the organization. However, in case of a shortage or non-existence of internal successors, organizations would need to find an external interim successor with the specific skills set and relevant experience for the future direction who can take over during emergencies. However, despite the careful selection, any interim successor introduces ambiguity and heightens the uncertainty of an already disruptive event (Ballinger \& Marcel, 2010; Mooney, et al., 2017). It is essential that a list of potential interim candidates for all leadership positions, not just the CEO, is ready for the possibility that an executive becomes ill. The current pandemic has highlighted the need for multiple succession candidates for key roles to be in place within the organization. Hence, emergency succession response needs to be taken seriously by the organisation's HR department as it directly impacts on the continuity of the organization. As such, this area requires additional support with immediate and in-depth studies conducted.

\subsubsection{Mental Health First Aid Training Programmes}

As mentioned earlier, employee productivity can be seriously affected if they are mentally unhealthy. To counteract this, mental health first aid training is gaining popularity in some organizations. This training can help employees recognize mental issues such as anxiety and depression among their colleagues enabling them to provide some assistance which can create a more supportive work environment. This training can also be extended to senior management with specific objectives to help the senior level employees to handle stressors at their level. Such training can include the implementation of positive mental health policies and transforming the workplace culture. Obviously, increasing wages and financial security can improve mental health problems. It is imperative that organizations focus on the emotional wellbeing of the employees. Mental health issues can be dealt with by arranging online consultations by organizations during pandemic. Additionally, in the event of salary reductions 
https://doi.org/10.15405/ejsbs.285

eISSN: 2301-2218 / Corresponding Author: Fadillah Ismail

Selection \& Peer-review under responsibility of the Editors

or retrenchment counseling can be offered as part of compensation packages that organizations can provide during a severe pandemic crisis.

During the 2009 H1N1 pandemic, the US Centers for Disease Control advised that all employers should be ready to implement strategies to protect their workforce from flu infections to ensure the continuity of operations (Centers for Disease Control and Prevention, 2010). This advice is currently a key recommendation during this current pandemic and will be a central part of guidance for any future pandemic caused by a respiratory virus, regardless of its severity level (Centers for Disease Control and Prevention, 2020).

\subsubsection{Flexible Policies}

The Covid-19 outbreak is forcing almost every business to immediately develop, adapt and improve policies and procedures at the workplace. It is a fact that employees' anxiety caused by pandemic's fallout have resulted in many employees reviewing their organisation's policies especially with regard to their physical well-being. Employees are afraid of becoming infected at workplace during a pandemic. They need to be confident that they will not be exposed to infections when they are at the workplace. Policies should be in place to permit employers to allow their sick staff to stay home and away from workplace. Implementing security measures in compliance with the standard operating procedures (SOPs) set by the government such as physical distancing, wearing face masks and frequent hand washing may protect employees from infections. Efforts to stop the viral outbreak include working from homes, instituting flexible working hours and remote operations are better and timely solutions. According to Spreitzer et al. (2017) and Spurk and Straub (2020), flexibility of work arrangements can be categorized within three dimensions: (a) flexibility in the scheduling of work, (b) flexibility in the location where work is accomplished, and (c) flexibility in the employment relationships. Whatever flexible work arrangements the organization wishes to implement according to its needs, it is essential to business continuity that the decisions be instituted as policies with minimal fuss to benefit employees' peace of mind and enhance their productivity.

\subsubsection{Role of the Human Resources Department}

Undoubtedly, the Human Resources Department (HR) has an integral role to play in managing the workforce and implementing contingency plans during such times of crisis, to minimize any disruption to normal operations. One of the most important responsibilities of the HR department is to ensure that the top management and the board are aligned on emergency succession planning. The second major role of the HR department is to make sure 
https://doi.org/10.15405/ejsbs.285

eISSN: 2301-2218 / Corresponding Author: Fadillah Ismail

Selection \& Peer-review under responsibility of the Editors

the revision of a succession plan is documented. Although, human resources professionals are involved in many of the immediate activities in an emergency transition, the major activities include planning for key roles, effective communication plans, compensation plans for key positions such as interims. The role of the chief of HR department in the succession planning process is to serve as the liaison to the board secretary, the board chair, and the vice chair (Santora, 2020).

The role of HR professionals in emergencies requires collaboration with emergency management (Van Wart \& Kapucu 2011). This collaboration may be facilitated by human resources professionals and possibly emergency management professionals becoming 'internal networkers' (Agranoff, 2014) in which they connect isolated line managers and workers to 'new ideas and practices, and to other like-minded managers and employees' safety practices.

\subsubsection{Training opportunities for upskills}

In only a few months, the Covid-19 outbreak has disrupted the livelihood of millions of young people around the world. Organizations who fail to adapt new norms of the pandemic affected working environment, will fail to survive. In this rapidly evolving digital economy, employees are required to gain knowledge in using advanced changing technologies at the workplace. Skills development programmes can help enhance employees' productivity thereby helping them remain relevant in the new environment.

Upskilling can involve the following;

Digital skills development: Some governments are now increasing their investments in digital skills development to ensure that youth can leverage online education and employment opportunities. One example is the African Development Bank Coding for Employment e-learning platform was launched in 2019 to equip African youth with advanced digital skills. Since the start of the pandemic, the number of users has increased by almost 50\% (Livari et al., 2020) have correctly concluded that "the COVID-19 pandemic initiated an extensive, sudden and dramatic digital transformation in the society" (p. 5).

Full time training programmes: Some countries such as Singapore have introduced full time training (6-12 months programmes) to get jobseekers ready for jobs when the economy recovers. These training programmes focus on high demand labour sectors such as health, manufacturing service, food services and so on. Similarly, in Germany, the Qualification Opportunities Act provides for government subsidies for companies' employees training programmes. In certain cases, up to 100 percent of training costs for microbusinesses and up to 50 percent for SMEs are covered by subsidies. 
https://doi.org/10.15405/ejsbs.285

eISSN: 2301-2218 / Corresponding Author: Fadillah Ismail

Selection \& Peer-review under responsibility of the Editors

\section{Discussion}

This study extends the previous literature on succession planning, specifically emergency succession planning. In the face of the collapse of numerous businesses, the contribution of this study is applicable to every sector in redirecting the focus to the importance of revitalising organisations' emergency succession plan during covid-19 pandemic to ensure business continuity. Identifying emergency replacements for the unexpected absence of key employees is critical for organizations to remain relevant during an emergency. The current Covid-19 crisis has underscored the need for having an emergency succession plan in place to ensure business continuity. The Covid-19 pandemic has forever transformed the workplace in many ways. It has established a new normal for business operations. Covid-19 has forced leaders across sectors to take immediate actions effectively and efficiently to handle the unstable changes. These include a review of CEO succession, organization policies, implementation of formal succession plans, effective communication plans, more diverse training opportunities and mental health programmes for their employees.

Some pandemics have diverse effects on the mental well-being of the population which changes human behavior due to the fear of losing jobs. Such anxiety affects many people which can lead to exhaustion of resources such as panic buying. It is not surprising that the anxiety caused by the pandemic has resulted in many organizations reviewing their policies. Reducing working days per week and reducing working hours per day might be some other options to support employees. The digitalization of the workforce will play an essential role in any company's success and especially now that most employees have to work remotely, skills development programmes can boost employees' productivity and reduce anxiety. Technological advances can stimulate a large-scale change in the demand for specific roles in the workforce which should be ready to embrace the change. In order for such policies to be implemented effectively, efficiently and in a timely manner, a list of the potential interim candidates for all key positions including CEO is essential in the event of the absence of the CEO or key employees.

The number of studies available on the psychological impacts of the Covid-19 outbreak is limited, particularly in the area of succession planning, both emergency and long term. This study has attempted to throw some light on this crucial issue by highlighting the differences between long-term and emergency succession planning, the major challenges faced by all organizations and, suggests best options for preparing emergency succession planning during the pandemic crisis. 
https://doi.org/10.15405/ejsbs.285

eISSN: 2301-2218 / Corresponding Author: Fadillah Ismail

Selection \& Peer-review under responsibility of the Editors

\section{Conclusions and Recommendations}

This paper provides a brief but cogent review of existing literature in the area of succession planning. The current Covid-19 outbreak has evolving from a health care crisis to a financial crisis, which has affected multiple sectors. Due to rapidity at which this disease is transmitted around the world, organizations need to prioritise emergency preparedness to ensure business continuity so that business operations can run smoothy with minimal interruptions caused by the pandemic. With a succession plan in place, there will be no need to start from scratch. Organisations have to learn lessons from the Covid-19 experience to strengthen their preparedness for the future.

The importance of having an emergency succession plan in place is not limited to a few sectors; it is an essential step for every sector especially those that must continue providing essential services during emergencies such as healthcare. While most people would say that the Covid-19 outbreak has caused immense heartache both professionally and socially, it cannot be denied that it has revealed the lack of preparedness of many organisations in terms of succession planning and effective policies to shield employees from the anxiety of working in different environments and even worse, losing their jobs. This pandemic has been a bitter lesson for organisations on the importance of being prepared to test the effectiveness of their emergency succession plan and employee related policies. Now, organisations must realise the need for optimizing their communication plan, implementing a formal succession plan, implementing flexible working policies, and instituting relevant training and mental health programmes at the workplace as part of their business continuity plan. Traditionally, succession plans are reviewed within a duration of one to three years, but Covid-19 has certainly changed all that; the Covid-19 virus has taught us many lessons, one of the most important is that it has become a wake-up call for organizations to revitalise their emergency succession plan immediately to cater for multiple leadership vacant positions from lower management right to the top management, and to prioritise employees' mental and physical well-being at all times.

\section{Acknowledgements}

The author(s) declare that there is no conflict of interest. 


\section{References}

Agranoff, R. (2014). Local governments in multilevel systems: emergent public administration challenges. American Review of Public Administration, 44(4), 47S-62S. https://doi.org/10.1177/0275074013497629

Ballinger, G. A., \& Marcel, J. J. (2010). The use of an interim CEO during succession episodes and firm performance. Strategic Management Journal, 31(3), 262-283. https://doi.org/10.1002/smj.808

Bartel, C. A., Wrzesniewski, A., \& Wiesenfeld, B. M. (2012). Knowing where you stand: Physical isolation, perceived respect, and organizational identification among virtual $\begin{array}{llll}\text { employees. } & \text { Organization } & \text { Science, } & \text { 23(3), }\end{array}$ https://doi.org/10.1287/orsc.1110.0661

Centers for Disease Control and Prevention. (2010). H1N1 flu ("swine flu") and you. https://www.cdc.gov/h1n1flu/qa.htm

Centers for Disease Control and Prevention. (2020). Interim Guidance for Businesses and Employers to Plan and Respond to Coronavirus Disease 2019 (COVID-19). https://www.cdc.gov/coronavirus/2019-ncov/specificgroups/ guidance-businessresponse.html

Ducharme, J. (2020, March 11). World Health Organization declares COVID-19 a 'pandemic. Here's what that means. Time. https://time.com/5791661/who-coronavirus-pandemicdeclaration/

Koonin, L. M. (2020). Novel coronavirus disease (COVID-19) outbreak: Now is the time to refresh pandemic plans. Journal of business continuity \& emergency planning, 13(4), $1-15$.

Lee, D. W., Lee, J., Kim, H. R., \& Kang, M. Y. (2020). Association of long working hours and health-related productivity loss, and its differential impact by income level: A cross-sectional study of the Korean workers. Journal of Occupational Health, 62(1), e12190. https://doi.org/10.1002/1348-9585.12190

Liang, Z. C., Ooi, S. B. S., \& Wang, W. (2020). Pandemics and their impact on medical training: lessons from Singapore. Academic Medicine, 95(9), 13591361. https://doi.org/10.1097/ACM.0000000000003441

Livari, N., Sharma, S., \& Ventä-Olkkonen, L. (2020). Digital transformation of everyday lifeHow COVID-19 pandemic transformed the basic education of the young generation and why information management research should care? International Journal of $\begin{array}{llll}\text { Information } \quad \text { Management, } & 102183 .\end{array}$ https://doi.org/10.1016/j.ijinfomgt.2020.102183

Mooney, C. H., Semadeni, M., \& Kesner, I. F. (2017). The selection of an interim CEO: Boundary conditions and the pursuit of temporary leadership. Journal of Management, 43(2), 455-475. https://doi.org/10.1177/0149206314535433

New Straits Times Business. (2020, September 17). Top Glove posted massive Q4 net profit of RM1.29bil, full-year at RM1.87bil. https://www.nst.com.my/business/2020/09/625312/top-glove-posted-massive-q4-netprofit-rm129bil-full-year-rm187bil

Nicola, M., Alsafi, Z., Sohrabi, C., Kerwan, A., Al-Jabir, A., Iosifidis, C., Agha, M., \& Agha, R. (2020). The socio-economic implications of the coronavirus and COVID-19 
pandemic: a review. International Journal of Surgery. Int J Surg., 78, 185-193. https://doi.org/10.1016/j.ijsu.2020.04.018

Ross, A. G., Crowe, S. M., \& Tyndall, M. W. (2015). Planning for the next global pandemic. Journal of Infectious Diseases, 38, 89-94. https://doi.org/10.1016/j.ijid.2015.07.016

Rothwell, W. J. (2011). Replacement planning: A starting point for succession planning and talent management. International Journal of Training and Development, 15(1), 87-99. https://doi.org/10.1111/j.1468-2419.2010.00370.x

Santora, J. C. (2020). COVID-19: An Urgent Imperative for CEO Succession Planning. Board Leadership, 170, 4-5. https://doi.org/10.1002/bl.30164

Sim, M. R. (2020). The COVID-19 pandemic: major risks to healthcare and other workers on the front line. Occup. Environ. Med., 77(5), 281-282. https://doi.org/10.1136/oemed2020-106567

Spreitzer, G. M., Cameron, L., \& Garrett, L. (2017). Alternative work arrangements: Two images of the new world of work. Annual Review of Organizational Psychology and Organizational Behaviour, 4, 473-499. https://doi.org/10.1146/annurev-orgpsych032516-113332

Spurk, D., \& Straub, C. (2020). Flexible employment relationships and careers in times of the COVID-19 pandemic. Journal of Vocational Behavior, 119,103435. https://doi.org/10.1016/j.jvb.2020.103435

Swanson, M. (2018). Employee Perceptions of Succession Planning within Higher Education: A Qualitative Case Study Doctoral Dissertations and Projects. 1777. https://digitalcommons.liberty.edu/doctoral/1777

Taubenberger, J. K., \& Morens, D. M. (2006). 1918 Influenza: the mother of all pandemics. Revista Biomedica, 17(1), 69-79. https://www.medigraphic.com/cgi$\mathrm{bin} / \mathrm{new} /$ resumenI.cgi? IDARTICULO $=13827$

Turkle, S. (Ed.). (2011). The Inner History of Devices. MIT Press.

Van Wart, M., \& Kapucu, N. (2011). Crisis management competencies: The case of emergency managers in the USA. Public Management Review, 13(4), 489-511. https://doi.org/10.1080/14719037.2010.525034

Wolfe, R. (1996). Systematic Succession Planning: Building Leadership from Within. Crisp Publications, Fredericton.

World Health Organization. (2020a). WHO Coronavirus Disease (COVID-19) Dashboard. Retrieved on 30 March, 2020, from https://covid19.who.int/table

World Health Organization. (2020b, May 14). Substantial investment needed to avert mental health crisis. https://www.who.int/news/item/14-05-2020-substantial-investmentneeded-to-avert-mental-health-

crisis\#: :text=\%E2\%80\%9CThe\%20impact $\% 20$ of $\% 20$ the $\% 20$ pandemic, of $\% 20$ income $\% 20$ and $\% 20$ often $\% 20$ employment. $\%$ E2\%80\%9D

Yeo, C., Kaushal, S., \& Yeo, D. (2020). Enteric involvement of coronaviruses: is faecal-oral transmission of SARS-CoV-2 possible? Lancet Gastroenterology \& Hepatology, 5(4), 335-337. https://doi.org/10.1016/S2468-1253(20)30048-0 